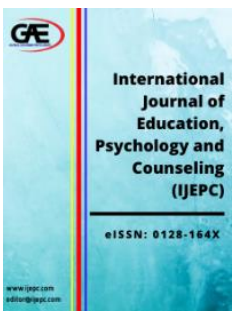

\author{
INTERNATIONAL JOURNAL OF \\ EDUCATION, PSYCHOLOGY \\ AND COUNSELLING \\ (IJEPC) \\ www.ijepc.com
}

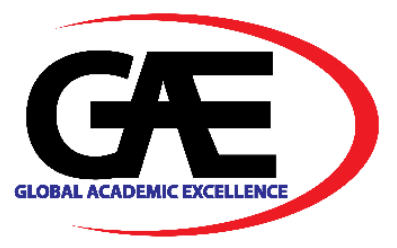

\title{
EXPLORATORY FACTOR ANALYSIS OF TPACK IN THE CONTEXT OF ESL SECONDARY SCHOOL TEACHERS IN SABAH
}

\author{
Ahmad Abdul Rauf ${ }^{1 *}$, Suyansah Swanto ${ }^{2}$, Syahrul Nizam Salam ${ }^{3}$ \\ 1 Faculty of Psychology And Education, Universiti Malaysia Sabah, Malaysia \\ Email: mattvandecro@gmail.com \\ 2 Faculty of Psychology And Education, Universiti Malaysia Sabah, Malaysia \\ Email: sswantospps1611@gmail.com \\ 3 The Centre For The Promotion of Knowledge And Language Learning, Universiti Malaysia Sabah, Malaysia \\ Email: insantakwa@yahoo.com \\ * Corresponding Author
}

\section{Article Info:}

Article history:

Received date: 21.10 .2020

Revised date: 02.12 .2020

Accepted date: 11.03.2021

Published date: 15.03.2021

To cite this document:

Rauf, A. A., Swanto, S., \& Salam, S. N. (2021). Exploratory Factor Analysis of TPACK in The Context of ESL Secondary School Teachers in Sabah. International Journal of Education, Psychology and Counseling, 6 (38), 137-146.

DOI: $10.35631 /$ IJEPC.6380012.

This work is licensed under $\underline{\mathrm{CC} B Y}$ 4.0

\begin{abstract}
:
The aim of this study was to adapt the Survey of EFL-Technological Pedagogical Content Knowledge (EFL-TPACK) by Bostancığlu \& Handley (2018) and to investigate its factor structure through exploratory factor analysis. 100 ESL teachers of secondary schools in Sabah participated in this study. SPSS application has been used for statistical analyses. The reliability of the subscales from Cronbach Alpha is ranging from 0.898 to 0.902. The final TPACK survey included a total of 33 items: 6 TK, 3 CK, 6 PK/PCK, 6 TCK, 6 TPK, and 6 TPACK. Based on the findings also, the TPACK Survey has been found to be ideal to study on TPACK level of English language teachers in Malaysia.
\end{abstract}

Keywords:

TPACK, ESL, Exploratory Factor Analysis (EFA), Sabah 


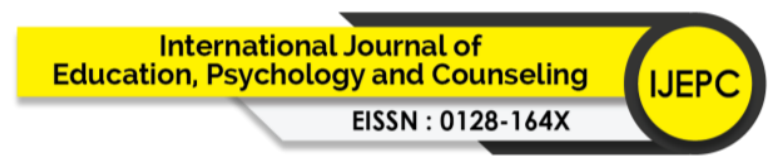

Volume 6 Issue 38 (March 2021) PP. 137-146 DOI 10.35631/IJEPC.6380012

\section{Introduction}

Today, in many countries around the world, the task of creating professional teachers in the 21 st century is a hotly debated issue that always being discussed. This is because, creating and training quality teachers are the keys to achieving quality education (Lin, et al., 2017), as the effectiveness of teachers is related to the quality of primary and secondary school graduates (Stronge, 2018, Ghavifekr \& Rosdy, 2015). Governments under their respective ministries have invested in school technology services and developed policies governing the use of technology to train teachers for today's new learning environments (Davis, 2014, UNESCO Bangkok, 2013, Kalolo, 2019). As schools are accustomed to the use of technology, teachers must also be prepared for their teaching to incorporate technology effectively into schools (Voogt \& McKenney, 2017, Tondeur, 2017). Preparing teachers whether in-service or preservice to successfully incorporate technology into classroom teaching is an ongoing problem that requires tools, training, and preparation to assist and direct teachers to accommodate themselves in schools.

Using ICT plays a major role for all teachers in incorporating technology. There are, however, many situations in which teachers are not trained to use technology of ICT in education and to incorporate it effectively into classroom training. The obstacles to technology adoption in teaching may be due to lack of access to technology adoption programs. It may also be due to lack of access to technology in schools and the fear that they would not be trained adequately. Efficient use of technology in teaching and learning requires the teacher to understand how technology relates to pedagogy and content. There are many studies in recent years focused on how teachers' knowledge and use of technology in schools can be enhanced and how technology integration can be established successfully. In today's classrooms where technology is increasingly growing, the need for a framework such as TPACK that helps teachers learn to use available learning technologies is something that very useful.

\section{Literature Review}

\section{Technological Pedagogical Content Knowledge}

Mishra and Koehler (2006) suggested Technological Pedagogical Content Knowledge (TPACK) framework from Shulman's (1987) pedagogical content knowledge (PCK) that clarifies the need to improve the knowledge of technology, pedagogy, and content separately and together in order to effectively incorporate technology into teaching. According to Schmidt et al (2009), the TPACK model aims to help teachers to design and evaluate instruction that effectively combines pedagogical content knowl $\neg$ edge and technology. This model also supports technology usage to ease learning difficulties and to develop new knowledge by using previous and existing knowlᄀedge in students (Koehler \& Mishra, 2009).

As illustrated in Figure 1, TPACK has three basic types of knowledge: Technological Knowledge (TK), Content Knowledge (CK) and Pedagogy Knowledge (PK). More precisely, technological knowledge (TK) refers to the ability of the teachers to operate technology ranging from marker pen and whiteboard to mobile devices and the Internet. Pedagogical knowledge $(\mathrm{PK})$ is characterized as the understanding of the procedures and strategies employed by teachers to schedule lessons, manage classrooms, and assess learning for students. Content knowledge (CK) is treated as the knowledge of teachers about subject matter content to be taught in class, for instance, English components and skills, such as vocabulary, grammar, reading, listening, speaking, and writing. Technical Pedagogical Knowledge (TPK) is 


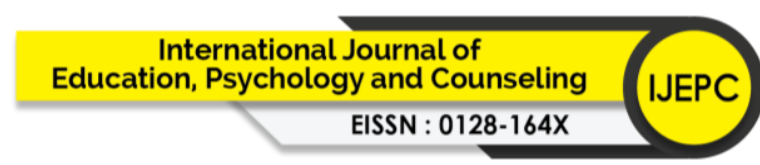

Volume 6 Issue 38 (March 2021) PP. 137-146

DOI 10.35631/IJEPC.6380012

conceptualized as the teachers' knowledge of using different pedagogical techniques to suit technical affordances. Technological Content Knowledge (TCK) on the other hand deals with the knowledge of the teachers on how subject matter is interpreted by the use of various technologies. Pedagogical Content Knowledge (PCK) is concerned with the knowledge of teachers in the execution of teaching strategies to reflect content, resolve learner difficulties and enhance understanding among students. Lastly, Technological Pedagogical Content Knowledge (TPCK) refers to knowledge about how technology can be used to represent content in pedagogically meaningful ways, as well as creating conditions and involving learners in learning processes. TPACK emphasizes the sensitivity of teachers to the complex, transactional relationships among all three knowledge components (technology, pedagogy, and content). The examples of each TPACK component can be seen in Table 1.

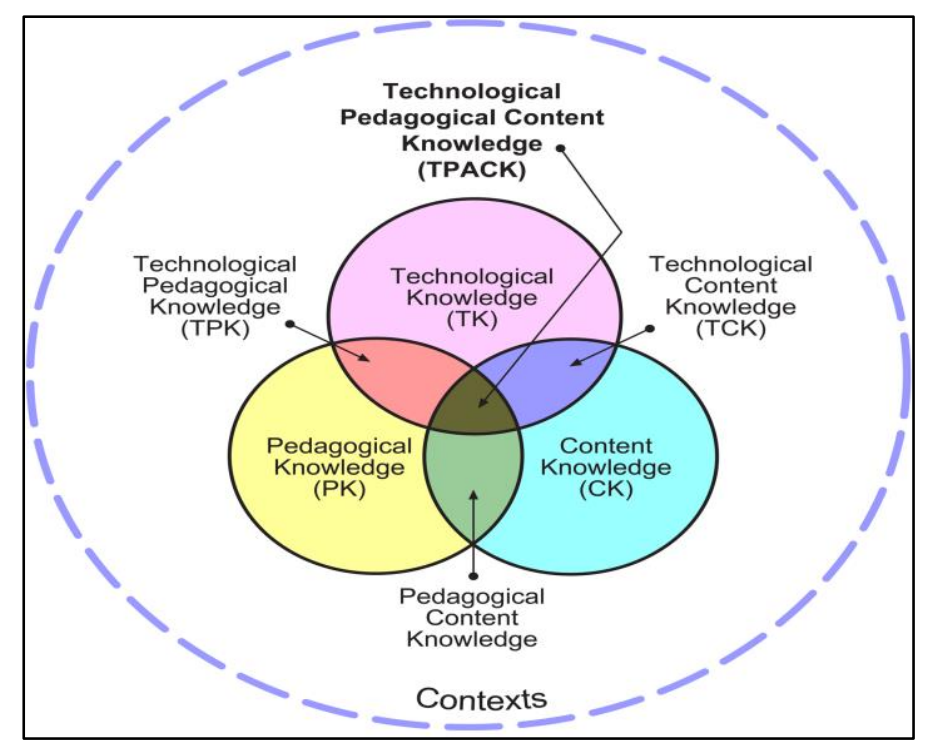

Figure 1: TPACK Framework

The TPACK system helps to direct teachers through on how to incorporate the technology, pedagogy, and content knowledge multiple domains. Thus, this framework can be defined as a teacher's understanding of when, where, and how to enhance student subject learning through appropriate technology-supporting instructional strategies (Koehler, Mishra, \& Yahya, 2007; Mishra \& Koehler, 2006; Niess, 2011). 
Table 1: TPACK Constructs, Definition And Examples

\begin{tabular}{|c|c|c|}
\hline $\begin{array}{c}\text { TPACK } \\
\text { Constructs }\end{array}$ & Definition & Example \\
\hline $\begin{array}{l}\text { Technological } \\
\text { Knowledge (TK) }\end{array}$ & $\begin{array}{l}\text { Knowledge about teacher's } \\
\text { ability to operate technology }\end{array}$ & $\begin{array}{l}\text { Teacher's ability to use web tools } \\
\text { such as Facebook, blogs etc. }\end{array}$ \\
\hline $\begin{array}{l}\text { Pedagogical } \\
\text { Knowledge (PK) }\end{array}$ & $\begin{array}{l}\text { Knowledge about teacher's } \\
\text { skills to schedule lessons, } \\
\text { manage classrooms, and assess } \\
\text { learning for students. }\end{array}$ & $\begin{array}{l}\text { Teacher's ability to use problem } \\
\text { based learning (PBL) in teaching } \\
\text { different language components } \\
\text { (writing, reading etc.). }\end{array}$ \\
\hline $\begin{array}{l}\text { Content } \\
\text { Knowledge (CK) }\end{array}$ & $\begin{array}{l}\text { Knowledge about teacher's } \\
\text { understanding of subject } \\
\text { matter }\end{array}$ & $\begin{array}{l}\text { Teacher's knowledge to use } \\
\text { suitable contents in class such as } \\
\text { vocabulary in writing essay. }\end{array}$ \\
\hline $\begin{array}{l}\text { Technological } \\
\text { Pedagogical } \\
\text { Knowledge (TPK) }\end{array}$ & $\begin{array}{l}\text { Knowledge about using } \\
\text { different pedagogical } \\
\text { techniques to suit technical } \\
\text { affordances. }\end{array}$ & $\begin{array}{l}\text { Knowledge about how to utilise } \\
\text { online tools such as Facebook or } \\
\text { Wiki to enhance collaborative } \\
\text { writing among students. }\end{array}$ \\
\hline $\begin{array}{l}\text { Technological } \\
\text { Content } \\
\text { Knowledge (TCK) }\end{array}$ & $\begin{array}{l}\text { Knowledge on how subject } \\
\text { matter is interpreted using } \\
\text { various technologies. }\end{array}$ & $\begin{array}{l}\text { Knowledge about how to use } \\
\text { illustrations to show the rules of } \\
\text { subject-verb-agreement. }\end{array}$ \\
\hline $\begin{array}{l}\text { Pedagogical } \\
\text { Content } \\
\text { Knowledge (PCK) }\end{array}$ & $\begin{array}{l}\text { Knowledge of adopting } \\
\text { relevant pedagogical strategies } \\
\text { to make learners understand } \\
\text { the subject matter. }\end{array}$ & $\begin{array}{l}\text { Knowledge about how to use } \\
\text { listening skills to teach speaking. }\end{array}$ \\
\hline $\begin{array}{l}\text { Technological } \\
\text { Pedagogical } \\
\text { Content } \\
\text { Knowledge } \\
\text { (TPACK) }\end{array}$ & $\begin{array}{l}\text { Knowledge of using various } \\
\text { technologies to teach and } \\
\text { represent the designated } \\
\text { subject content. }\end{array}$ & $\begin{array}{l}\text { Knowledge to use mobile learning } \\
\text { technologies such as Facebook as a } \\
\text { communicating tool to enhance } \\
\text { collaborative learning in a writing } \\
\text { class. }\end{array}$ \\
\hline
\end{tabular}

\section{TPACK Survey Instruments}

A number of TPACK survey instruments have been developed by researchers throughout the years to study teachers' TPACK level from various disciplines through statistical procedures of testing validity and reliability. The first pilot study that used TPACK instrument was conducted by Schmidt et al. (2009). In the study, the had developed 75 survey items administered to 124 pre-service teachers in a university in the USA. The instrument catered subjects of literacy, mathematics, science, and social studies on the aspects of teaching and learning. Then, the study by Chai, et al., (2011) used a 46 items TPACK instrument for their study on pre-service elementary teachers in Singapore. This was followed by Sahin (2011) who assessed 348 pre-service teachers' perceptions of their TPACK using a 47-items survey. 


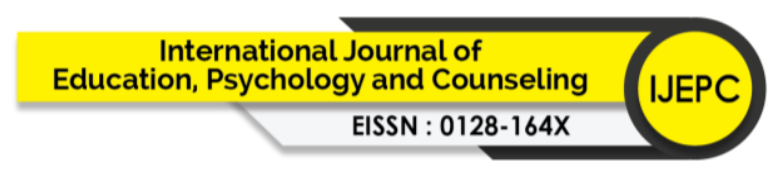

Volume 6 Issue 38 (March 2021) PP. 137-146

DOI 10.35631/IJEPC.6380012

Those instruments mostly focused on a variety of subject-matter areas such as science and mathematics. The need to have a valid and reliable TPACK survey developed for EFL or ESL teachers specifically also had seen some researchers had developed instruments just focusing on language teaching. For this purpose, there were various studies that developed TPACK instrument in the field of language teaching. For example, Chai, et al., (2013) used TPACK instrument purposely to assess TPACK level of teachers who teach Chinese as a second language in Singapore. Baser, et al., (2016) developed their own instrument to measure TPACK level of pre-service English language in Turkey. They focused towards the educational technology integration and how technology could support the teaching of English language. According to Bostancioğlu \& Handley (2018), both instruments had some limitations like influenced by certain thoughts or theories and restrictions to certain use of technologies of the learners. These limitations urged for the development of EFL-TPACK instrument developed by Bostancioğlu \& Handley.

For this study, the researcher used an instrument by Ali Bostancioğlu \& Zoe Handley (2018). They had developed a 36 items TPACK instrument specifically for measuring TPACK among teachers of EFL that was called EFL-TPACK instrument. In developing the instrument, Bostancioğlu \& Handley had followed three stages of (1) item pool genetation, (2) content validation and (3) construct validation. They finally reported the validity, consistency and reliability of the new instrument through Confirmatory factor analysis (CFA), thus making it a valid and reliable tool in measuring TPACK level among teachers of EFL or ESL.

\section{Research Objective}

To adapt the Survey of EFL-Technological Pedagogical Content Knowledge (EFL-TPACK) by Bostancioğlu \& Handley into Malaysian context and to investigate its factor structure through Exploratory Factor Analysis (EFA).

\section{Research Methodology}

\section{Sample}

The target population for this study was the ESL secondary school teachers in Sabah. This study randomly selected 100 ESL teachers from the total population of 1200 to be used as simple random sampling. The number of samples is adequate for the purpose of doing an Exploratory Factor Analysis (EFA) study (Hair, et al., 2016). The data is analysed using EFA for establishing the rotated component analysis that has been used for significance of items in the model.

\section{Instrument}

The EFL-TPACK Survey developed by Ali Bostancioğlu \& Zoe Handley (2018) was used in this study. This 36 items-survey is scored as Strongly Disagree =1, Disagree =2, Neither Agree nor Disagree $=3$, Agree =4, Strongly Agree $=5$. There are no any negative statements in the survey. The distribution of items for this survey can be seen in table 2 below. 
Table 2: Dimensions and Number of Items of EFL-TPACK Instrument

\begin{tabular}{lc}
\hline \multicolumn{1}{c}{ Dimensions } & No of Items \\
\hline Technology Knowledge (TK) & 6 \\
$\begin{array}{l}\text { Pedagogy Knowledge (PK) / } \\
\text { Pedagogical Content Knowledge (PCK) }\end{array}$ & 7 \\
Content Knowledge (CK) & 5 \\
Technological Content Knowledge (TCK) & 6 \\
$\begin{array}{l}\text { Technological Pedagogical Knowledge } \\
\text { (TPK) }\end{array}$ & 6 \\
$\begin{array}{l}\text { Technological Pedagogical Content } \\
\text { Knowledge (TPCK) }\end{array}$ & 6 \\
\hline \multicolumn{1}{c}{ TOTAL } & 36
\end{tabular}

\section{Data Analysis}

The construct validity of the EFL-TPACK Survey was tested through EFA before Cronbach Alpha reliability coefficients of subscales were reported. Then, the item total correlations were computed for item discrimination. Table 3 shows the value for Bartlett's Test which is significant (P-Value < 0.05 ) and also the measure of sampling adequacy by Kaiser-MeyerOlkin (KMO) is 0.782 which is higher than the minimum requirement of 0.6 (Awang, 2012).

Table 3: KMO and Bartlett's Test

\begin{tabular}{llr}
\hline Kaiser-Meyer-Olkin Measure of Sampling & .782 \\
Adequacy. & & \\
Bartlett's Test of & Approx. Chi-Square & 2207.009 \\
Sphericity & df & 630 \\
& Sig. & .000 \\
\hline
\end{tabular}

The results of the pilot study also show the reliability value index of 0.902 (very good reliability or acceptable standardised test for internal consistency) as shown in Table 4. This is at the degree of positive correlation level. According to Hair, et al., (2016), the value for Cronbach's Alpha for an instrument should exceed the value of 0.7 for it to be accepted in the subsequent studies. The value of 0.7 and above indicates that the instrument has high reliability standards. Thus, the reliability results of the pilot study are important to uphold the precision of research instruments. The higher the value and level of the validity and reliability of the instrument, the accuracy of the data will be derived later (Ghazali et.al, 2016). 
Table 4: Chronbach's Alpha

\begin{tabular}{|c|c|c|}
\hline & $\begin{array}{c}\text { Cronbach's } \\
\text { Alpha Based } \\
\text { on } \\
\text { Cronbach's } \\
\text { Alpha }\end{array}$ & $\begin{array}{c}\text { Standardized } \\
\text { Items }\end{array}$ \\
\hline .902 & N of \\
Items \\
\hline
\end{tabular}

\section{Results}

\section{Exploratory Factor Analysis Findings}

Based on the Survey of EFL-Technological Pedagogical Content Knowledge (EFL-TPACK), there are six dimensions outlined in the instrument. The total variance for those six dimensions is 70.706. According to Awang (2012), Hoque et al., (2017), the minimum requirement of total variance is $60 \%$. If the value is lower than $60 \%$, it indicates the existing items are inadequate to measure the construct, thus making the researcher to build or add a few items for the respective construct.

Hair, et al., (2016) mentioned that factor loadings between the range of \pm .30 to \pm .40 considered to meet the minimal level for interpretation of structure while loadings \pm .50 or greater are considered practically significant. They also indicated that factor loadings can be based on sample size. For example, in a sample of 100 respondents, factor loadings of .55 and above are considered significant. Items that have values lower than .55 are then deleted. The range values of factor loadings and items deleted are shown in Table 5 below. As can be seen, a total of six items are deleted from being used in the subsequent study since they have a loading factor value of less than .55 .

Table 5: Factor Loadings and Deleted Items

\begin{tabular}{llcc}
\hline No & \multicolumn{1}{c}{ Items } & $\begin{array}{c}\text { Factor } \\
\text { Loadings }\end{array}$ & Item(s) Deleted \\
\hline 1 & TK (Technology Knowledge) & .663 to .792 & TK6 \\
2 & $\begin{array}{l}\text { PK (Pedagogy Knowledge) / } \\
\text { PCK (Pedagogical Content Knowledge) }\end{array}$ & .587 to .761 & $\begin{array}{c}\text { PK/PCK1 \& } \\
\text { PK/PCK3 }\end{array}$ \\
3 & CK (Content Knowledge) & CK1 \& CK5 \\
4 & TCK (Technological Content Knowledge) & .591 to .882 & - \\
5 & TPK (Technological Pedagogical Knowledge) & .695 to .782 & - \\
6 & $\begin{array}{l}\text { TPCK (Technological Pedagogical Content } \\
\text { Knowledge) }\end{array}$ & .650 to .916 & TPCK3 \\
\hline
\end{tabular}




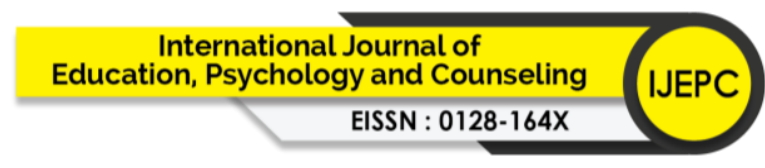

Volume 6 Issue 38 (March 2021) PP. 137-146 DOI 10.35631/IJEPC.6380012

\section{Conclusion}

The purpose of this study was to adapt the Survey of EFL-Technological Pedagogical Content Knowledge (EFL-TPACK) by Bostancioğlu \& Handley into Malaysian context and to investigate its factor structure through Exploratory Factor Analysis (EFA). The participants were 100 ESL secondary school teachers from the state of Sabah. The present study contributes to the measurement of TPACK construct, particularly in the context of ESL secondary school teachers in the state of Sabah. The EFA results of the present study produced a structure which extracts six dimensions of TPACK. The dimensions are Technology Knowledge (TK), Pedagogy Knowledge (PK) / Pedagogical Content Knowledge (PCK), Content Knowledge (CK), Technological Content Knowledge (TCK), Technological Pedagogical Knowledge (TPK), Technological Pedagogical Content Knowledge (TPCK). All reliability measures for the six dimensions or components of TPACK construct showed high Cronbach's Alpha value, met Bartlett Test achievements (significant), KMO (>0.6), and exceeded 0.60 of factor loadings. This reflects that the items that are not set aside, are applicable in this study. The rigorous scale development and validation procedures of the present study have ensured that the EFL-TPACK instrument adapted in this study is internally consistent and stable across samples, thus appropriate to be conducted in Malaysian education system for studies on ESL teachers.

\section{References}

Akhir, A. M., Taat, M. S., \& Salam, S. N. (2020). Pengaruh Sikap, Kesediaan Guru Dan Efikasi-Kendiri Guru Terhadap Komuniti pembelajaran Profesional. International Journal of Modern Education, 2(7), 76-89.

Akhir, A. M., Taat, M. S., \& Salam, S. N. (2020). Hubungan Sikap, Kesediaan Guru Dan Efikasi-Kendiri Guru Dengan Komuniti pembelajaran Profesional. International Journal of Education, Psychology and Counseling, 5 (37), 221-231.

Ali Bostancığlu \& Zoe Handley (2018): Developing and Validating a Questionnaire for Evaluating the EFL 'Total PACKage': Technological Pedagogical Content Knowledge (TPACK) for English as a Foreign Language (EFL), Computer Assisted Language Learning, DOI: 10.1080/09588221.2017.1422524

Adriana Muhamad Akhir, Muhamad Suhaimi Taat, Syahrul Nizam Salam (2020). Pengaruh Sikap, Kesediaan Guru Dan Efikasi-Kendiri Guru Terhadap Komuniti pembelajaran Profesional. International Journal of Modern Education, 2(7), 76-89.

Adriana Muhamad Akhir, Muhamad Suhaimi Taat, Syahrul Nizam Salam .(2020). Hubungan Sikap, Kesediaan Guru Dan Efikasi-Kendiri Guru Dengan Komuniti pembelajaran Profesional. International Journal of Education, Psychology and Counseling, 5 (37), 221-231.

Awang, Z. (2012). Structural Equation Modeling Using AMOS Graphic. Penerbit Universiti Teknologi MARA.

Baser, D., Kopcha, T. J., \& Ozden, M. Y. (2016). Developing a technological pedagogical content knowledge (TPACK) assessment for preservice teachers learning to teach English as a foreign language. Computer Assisted Language Learning, 29(4), 749-764.

Chai, C.-S., Koh, J.H.-L., Tsai, C.-C., \& Tan, L.L.W. (2011). Modeling primary school preservice teachers' Technological Pedagogical Content Knowledge (TPACK) for meaningful learning with information and communication technology (ICT). Computers \& Education, 57, 1184-1193

Chai, C.-S., Chin, C.K., Koh, J.H.-L., \& Tan, C.L. (2013). Exploring Singaporean Chinese Language Teachers' Technological Pedagogical Content Knowledge and its 


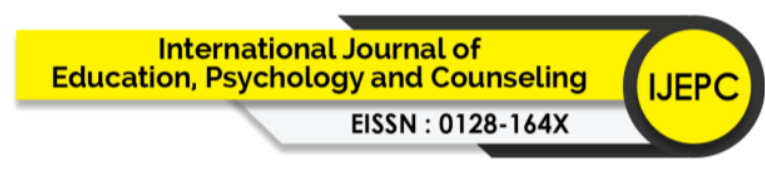

Volume 6 Issue 38 (March 2021) PP. 137-146 DOI 10.35631/IJEPC.6380012

Relationship to the Teachers' Pedagogical Beliefs. Asia-Pacific Education Researcher, 22(4), 657-666. doi:10.1007/s40299-013-0071-3

Davis, P. (2014). The Impact of Mobile Technology on Teaching and Learning in the Undergraduate Population. Maxine Smith Fellowship, 1-9.

Ghavifekr, S., \& Rosdy, W. A. W. (2015). Teaching and learning with technology: Effectiveness of ICT integration in schools. International Journal of Research in Education and Science, 1(2), 175-191.

Ghazali Darusalam \& Sufean Hussin (2016). Metodologi Penyelidikan Dalam Pendidikan: Amalan dan Analisis Kajian, 2nd Edition. Publisher: University of Malaya Press

Hair, J. F., Black, W. C., Babin, B. J., \& Anderson, R. E. (2016). Multivariate Data Analysis (Seventh ed.). Pearson Education Limited.

Hoque, A. S. M. M.; Awang, Z.; Jusoff, K.; Salleh, F.; \& Muda, H. (2017c). Social Business Efficiency: Instrument Development and Validation Procedure using Structural Equation Modelling, International Business Management, 11(1), 222-231

Kalolo, J.F. (2019). Digital Revolution and its Impact on Education Systems in Developing Countries. Education Information Technology 24, 345-358 (2019). https://doi.org/10.1007/s10639-018-9778-3

Koehler, M. J., Mishra, P., \& Yahya, K. (2007). Tracing the development of teacher knowledge in a design seminar: Integrating content, pedagogy and technology. Computers \& Education, 49(3), 740-762.

Koehler, M., \& Mishra, P. (2009). What is technological pedagogical content knowledge (TPACK)? Contemporary issues in technology and teacher education, 9(1), 60-70.

Lin, MH., Chen, HC., Liu, KS. (2017). A Study of the Effects of Digital Learning on Learning Motivation and Learning Outcome. EURASIA Journal of Mathematics Science and Technology Education. 2017 13(7):3553-3564.

Mishra, P., \& Koehler, M. J. (2006). Technological pedagogical content knowledge: A framework for teacher knowledge. Teachers college record, 108(6), 1017-1054.

Musa, M. H., Andin, C., Salam, S. N. (2020). Kesahan Dan Kebolehpercayaan Instrumen Pentaksiran Kemahiran Insaniah Murid (IPKIM) Mata Pelajaran Rekacipta. International Journal of Education, Psychology and Counseling, 5 (37), 96-107.

Mohd Hussin Musa, Christina Andin \& Syahrul Nizam Salam. (2020). Kesahan Dan Kebolehpercayaan Instrumen Pentaksiran Kemahiran Insaniah Murid (IPKIM) Mata Pelajaran Rekacipta. International Journal of Education, Psychology and Counseling, 5 (37), 96-107.

Niess, M. L. (2011). Investigating TPACK: Knowledge growth in teaching with technology. Journal of educational computing research, 44(3), 299-317.

Norin Farizah Mohd Nuin, and Abdul Said Ambotang, and Syahrul Nizam Salam. (2020) Pengaruh motivasi dan kompetensi terhadap perubahan pengurusan data murid di Sabah. International Journal of Education, Psychology and Counselling, 5 (34). pp. 116-125. ISSN 0128-164X

Nuin, N. F. M., Ambotang, A. S., \& Salam, S. N. (2020). Pengaruh Motivasi dan Kompetensi terhadap Perubahan Pengurusan Data Murid di Sabah. International Journal of Education, Psychology and Counseling, 5 (34), 116-125.

Osman Said, Mohd. Nasir Rayung, Syahrul Nizam Salam \& Abdul Said Ambotang .(2020). Pengaruh Sikap Guru, Pengetahuan Guru dan Kemahiran Guru Terhadap Kompetensi Pengurusan Disiplin Sekolah Kebangsaan di Sabah. International Journal of Education, Psychology and Counseling, 5 (35), 188-205 


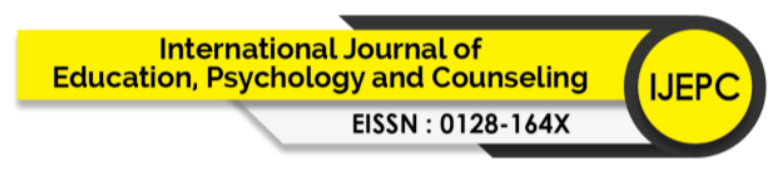

Volume 6 Issue 38 (March 2021) PP. 137-146 DOI 10.35631/IJEPC.6380012

Sahin, I. (2011). Development of survey of technological pedagogical and content knowledge (TPACK). Turkish Online Journal of Educational Technology - TOJET, 10(1), 97-105

Said, O., Rayung, M. N., Salam, S. N., \& Ambotang, A. S. (2020). Pengaruh Sikap Guru, Pengetahuan Guru dan Kemahiran Guru Terhadap Kompetensi Pengurusan Disiplin Sekolah Kebangsaan di Sabah. International Journal of Education, Psychology and Counseling, 5 (35), 188-205.

Schmidt, D. A., Baran, E., Thompson, A. D., Mishra, P., Koehler, M. J., \& Shin, T. S. (2009). Technological Pedagogical Content Knowledge (TPACK): The Development and Validation of an Assessment Instrument for Preservice Teachers. Journal of Research on Technology in Education, 42(2), 123-149.

Shulman, L. (1986). Those who understand: Knowledge growth in teaching. Educational Researcher, 15(2), 4-14. doi:10.3102/0013189X015002004

Stronge, J. H. (2018). Qualities of effective teachers. ASCD.

Syahrul Nizam Salam, Abdul Said Ambotang, Ghazali Hassan Sulaiman. (2018). Pengaruh Faktor Penyumbang Terhadap Kendiri Pelajar Ekonomi Tingkatan Enam Di Sabah. Jurnal Penyelidikan Akademik Kementerian Pendidikan Malaysia, 3 (34)

Syahrul Nizam Salam, Abdul Said Ambotang, Ghazali Hassan Sulaiman .(2019). Hubungan Sikap Terhadap Ekonomi Dan Kefahaman Konsep Ekonomi Dengan Kendiri Pelajar Ekonomi. Jurnal Kurikulum Kementerian Pendidikan Malaysia, 4(34), 16-29

Tondeur, J., Pareja Roblin, N., van Braak, J., Voogt, J., \& Prestridge, S. (2016). Preparing Beginning Teachers for Technology Integration in Education: Ready for Take-Off? Technology, Pedagogy and Education, 26(2), 157177.doi:10.1080/1475939x.2016.1193556

UNESCO Bangkok. (2013). Case studies on integrating ICT into teacher education curriculum in Asia. Bangkok: UNESCO, Asia and Pacific Regional Bureau for Education.

Voogt, J., \& McKenney, S. (2017). TPACK in teacher education: Are we preparing teachers to use technology for early literacy?. Technology, pedagogy and education, 26(1), 6983. 